\title{
Preparation of Reference Material for Proficiency Test for Enumeration of Coliforms in Cheese Matrix
}

\author{
Marcelo Luiz Lima Brandão ${ }^{*}$, Carla de Oliveira Rosas ${ }^{1}$, Silvia Maria Lopes Bricio ${ }^{1}$, \\ Valéria de Mello Medeiros ${ }^{1}$, Juliana de Castro Beltrão da Costa ${ }^{1}$, Rodrigo Rollin Pinheiro ${ }^{1}$, \\ Paola Cardarelli-Leite ${ }^{1}$, Marcus Henrique Campino de La Cruz ${ }^{2}$, Armi Wanderley da Nóbrega ${ }^{2}$ \\ ${ }^{1}$ Laboratory of Products, Department of Microbiology, National Institute of Quality Control in Health, Oswaldo Cruz Foundation, \\ Rio de Janeiro, Brazil; ${ }^{2}$ Proficiency Testing Program of Products Subject to Health Surveillance, National Institute of Quality Control \\ in Health, Oswaldo Cruz Foundation, Rio de Janeiro, Brazil. \\ Email: ${ }^{*}$ marcelo.brandao@incqs.fiocruz.br
}

Received June $6^{\text {th }}, 2013$; revised July $10^{\text {th }}, 2013$; accepted July $17^{\text {th }}, 2013$

Copyright (C 2013 Marcelo Luiz Lima Brandão et al. This is an open access article distributed under the Creative Commons Attribution License, which permits unrestricted use, distribution, and reproduction in any medium, provided the original work is properly cited.

\begin{abstract}
It is widely accepted that quantitative reference materials (RM), are indispensable tools for verification of the precision and accuracy of analytical measurements. The RM can be used by food microbiology laboratories, as part of their quality assurance programmes, to achieve their quality control. In Brazil, Anvisa RDC No. 12/01 specifies the enumeration of coliforms as one of the parameters for evaluating cheese quality. The aim of this study was to produce a quantitative $\mathrm{RM}$ for proficiency testing (PT) for use in the testing of enumeration of coliforms in cheese matrixes. A sample of an ultra-filtered cheese with a coliforms count of $<3.0 \mathrm{MPN} / \mathrm{g}$ and a total $\mathrm{n}^{\circ}$ of viable aerobes of $1.2 \times 10^{3} \mathrm{CFU} / \mathrm{g}$ was used as the matrix to produce the RM. The ultra-filtered cheese matrix was distributed in flasks, contaminated with a specific concentration of an Escherichia coli strain and submitted to freeze-drying. Sucrose was used as the cryo-protector. The $\mathrm{RM}$ produced was considered sufficiently homogeneous and stable at $\leq-70^{\circ} \mathrm{C}$ during the entire study period (348 days). The material was also considered sufficiently stable at $4^{\circ} \mathrm{C}$ for six days, but instable at $30^{\circ} \mathrm{C}$ and $35^{\circ} \mathrm{C}$ for the same period. At $-20^{\circ} \mathrm{C}$ the $\mathrm{RM}$ was sufficiently stable for 161 days. It was concluded that the material showed all the necessary requirements for a quality $\mathrm{RM}$ to be used as PT items and could be transported to the laboratories taking part in a PT at up to $4^{\circ} \mathrm{C}$ for up to 6 days, since the results indicated maintenance of the cell concentrations during this period. This is the first study to describe a methodology for producing RM containing coliforms in a cheese matrix.
\end{abstract}

Keywords: Coliforms; Cheese; Reference Material; Proficiency Test

\section{Introduction}

Food safety and quality are two of the most important factors determining the consumer acceptance and purchase dynamics of a product. Laboratories of food microbiology are extremely important in the performance of productive sector and for the control of the sanitary-hygienic quality. Official food control laboratories are required to use validated methods wherever possible. For this reason, analytical methods must be subjected to internal and/or external validation studies [1].

It is widely accepted that quantitative reference materials (RM), are indispensable tools for verification of the precision and accuracy of analytical measurements [2].

\footnotetext{
"Corresponding author.
}

The RM can be used by food microbiology laboratories, as part of their quality assurance programmes, to achieve their quality control, method validation, staff training control and evaluation of the laboratory's performance [3]. Furthermore, they are employed in laboratory accreditation, as well as in the establishment of traceability in the framework of internationally agreed standards [1]. The formal recognition of the technical competence of assay laboratories, including food microbiology laboratories, is done by accreditation to the ISO/IEC 17025 standard [4]. The use and traceability of RM, as well as the laboratory participation in proficiency testing (PT) schemes by interlaboratory comparisons are requirements of the aforementioned standard [4].

According to ISO guide 35, a RM is a "material, suffi- 
ciently homogeneous and stable with respect to one or more specific properties, which has been established to be fit for its intended use in a measurement process" [5]. To be considerate RM for food microbiology exams, the number of organisms present must be distributed homogeneously over the units of the batch and must remain stable over a determinate period of time [2].

A great variety of techniques and matrix supports have been used to produce homogenous and stable microbiological RM. Spray-dried is a common technique used to prepare large batch of contaminated milk powder capsules $[6,7]$. The freeze-drying by lyophilization has also been used in the production of RM in the field of food microbiology [8-11]. The main challenge in RM production destined to microbiological assays is the natural instability of micro-organisms, which difficult the development and maintenance of these RM [2]. The principal advantage of the lyophilized material is to allow storage for long periods with low risk of contamination. However, these methods cause damage to the microbial cells and the survival rate of many micro-organisms is low after the rehydration [12]. To circumvent these problems, some authors emphasize the importance of the use of cryo-protector, such as carbohydrates, during the processes of freezing and desiccation, with the goal of increasing the viability of bacterial cells [13]. Sucrose has been one of the most commonly carbohydrate used and presented satisfactory results in the production of food RM containing micro-organisms [11].

In Brazil, the Anvisa RDC No. 12/01 specifies the enumeration of coliforms as one of parameters for evaluating cheese quality [14]. Soon, food microbiology laboratories in Brazil must be able to perform this testing and provide reliable results. This study aimed to present and discuss the preparation of a quantitative RM for PT for use in enumeration assays of coliforms in cheese matrixes.

\section{Materials and Methods}

The RM was prepared following ISO guide 34 "General requirements for the competence of reference materials producers" [15].

\subsection{Strain}

The E. coli type I strain No. 03 was used to produce the RM. This strain was isolated from a sample of whole fresh lettuce and his identity was determinate with Vitek ${ }^{\circledR} 2$ Compact (bioMérieux), API 20E (bioMérieux) and classic method IMViC (++--), where I = indole production, $\mathrm{M}=$ methyl red reaction, $\mathrm{V}=$ VogesProskauer reaction (production of acetoin), and $\mathrm{C}=$ citrate utilization [16]. This strain was deposited in the Collection of Reference Micro-organisms in Health

\section{Surveillance in INCQS/Fiocruz.}

\subsection{Selection of the Matrix}

An ultra-filtered cheese sample previously analyzed and confirmed free of coliforms $(<3.0 \mathrm{MPN} / \mathrm{g})$ was used as matrix to produce the RM. The total viable aerobic microbial load in this matrix was also evaluated by pour-plate technique described by Maturin and Peeler [17]. Two grams of the ultra-filtered cheese matrix were weighed into sterile glass vials of $10 \mathrm{~mL}$ capacity (Schott, Brazil) until a total of 216 vials. The vials were frozen at freezer $\leq-70^{\circ} \mathrm{C}$ (Thermo, USA) for $24 \mathrm{~h}$ and lyophilized for $24 \mathrm{~h}$ below $-105^{\circ} \mathrm{C}$ under pressure lower than $13 \mathrm{~Pa}$ (0.1 mmHg; Liotop, São Carlos, SP, Brazil).

\subsection{Preparation of the Reference Material}

The E. coli strain (item 2.1) was streaked for purity on sheep blood agar (Merck, Germany) and incubated for 24 $\mathrm{h}$ at $35^{\circ} \mathrm{C} \pm 2^{\circ} \mathrm{C}$. After incubation, a single colony was suspended in $10 \mathrm{~mL}$ brain heart infusion broth (Merck, Germany) and incubated for $24 \mathrm{~h}$ at $35^{\circ} \mathrm{C} \pm 2^{\circ} \mathrm{C}$. Then, $0.5 \mathrm{~mL}$ of the culture were transferred to $15 \mathrm{~mL}$ of Luria Bertani broth (Difco, USA) with $10 \%$ of $\mathrm{NaCl}$ and incubated for $28 \mathrm{~h}$ at $35^{\circ} \mathrm{C} \pm 2^{\circ} \mathrm{C}$. After, the culture was centrifuged, and the pellet washed, three times, with $0.1 \%$ peptone saline solution (PSS) and suspended with 2 $\mathrm{mL}$ of PSS. The concentration of the suspension was adjusted using a colorimeter (Libra S2, Biochrom, England) at $520 \mathrm{~nm}$ until a transmission value of $2 \%$ (approximately $5 \times 10^{9}$ cells $/ \mathrm{mL}$ ) and diluted in PSS to achieve a concentration of $5 \times 10^{5}$ cells $/ \mathrm{mL}$. Two milliliters of the cell suspension were added to $198 \mathrm{~mL}$ of PSS containing $100 \mathrm{mM}$ sucrose (used as cryo-protector) and homogenized in a magnetic stirrer (PC-410, Corning, USA) for $30 \mathrm{~min}$ in an ice bath. Portions $(0.5 \mathrm{~mL})$ were distributed into sterile glass vials containing the lyophilized cheese (item 2.2), frozen at $\leq-70^{\circ} \mathrm{C}$ for $24 \mathrm{~h}$ and lyophilized for $24 \mathrm{~h}$ below $-105^{\circ} \mathrm{C}$ under pressure lower than $13 \mathrm{~Pa}$ (0.1 mmHg; Liotop, São Carlos, SP, Brazil). The vials were numbered and sealed with aluminum caps under vacuum and stored at $\leq-70^{\circ} \mathrm{C}$.

\subsection{Microbiological Examinations}

The cell quantification of vials was realized using the solid medium method described in the Bacteriological Analytical Manual-FDA [16]. The freeze-dried material was reconstituted with $2.0 \mathrm{~mL}$ of $0.1 \%$ PSS and incubated at room temperature. After $15 \mathrm{~min}$, the matrix was transferred to a sterile plastic bag filter (Nasco, USA) followed by addition of $16 \mathrm{~mL}$ of $0.1 \%$ SSP to reach the proportion 1:10. The bag was homogenized in stomacher apparatus (Seward, Fisher Scientific, Canada) for $1 \mathrm{~min}$. 
Aliquots of $1.0 \mathrm{~mL}$ were plated, in duplicate, by pourplate technique, in $10 \mathrm{~mL}$ of Violet red bile agar (VRBA) (Difco, USA) until solidification. After this time, a 10 $\mathrm{mL}$ VRBA overlay was added, and the plates were incubated at $35^{\circ} \mathrm{C} \pm 2^{\circ} \mathrm{C}$ for $24 \mathrm{~h}$. Later, the purple-red colonies on plates were enumerated and the counts were converted to $\log _{10} / \mathrm{g}$.

\subsection{Homogeneity Assessment}

For the homogeneity study, 24 vials taken randomly were enumerated under repeatability conditions, using the methodology described previously (item 2.4). The data were subjected to statistical analysis described in the International Harmonized Protocol for the Proficiency Testing of Analytical Chemistry Laboratories [18] assigning a standard deviation for proficiency assessment $\left(\sigma_{\mathrm{p}}\right)$ of 0.35 . The material was considered homogeneous if: $s_{\text {sam }}^{2}<c$; where $s_{\text {sam }}^{2}$ is the between-sample variance of the batch, and $c$ is the critical value.

\subsection{Stability Assessment}

Two types of stability tests were done: a long-term stability test at reference temperature $\left(\leq-70^{\circ} \mathrm{C}\right)$ and at storage temperature $\left(-20^{\circ} \mathrm{C}\right)$; and a short-term stability test at higher temperatures simulating transport conditions $\left(4^{\circ} \mathrm{C}, 30^{\circ} \mathrm{C}\right.$ and $\left.35^{\circ} \mathrm{C}\right)$. The enumeration assays were realized using the methodology described previously (item 2.4). For testing the stability of the material stored at $\leq-70^{\circ} \mathrm{C}, 26$ vials were examined, two per assay, at regular times intervals until a total of 348 days (classic approach) [5]. For testing the stability at $-20^{\circ} \mathrm{C}, 22$ vials were stored at $-20^{\circ} \mathrm{C}$ and two vials stored at $\leq-70^{\circ} \mathrm{C}(0$ day) were examined, two per assay, at regular times intervals until a total of 161 days (classic approach) [5]. The stability of the material stored at high temperatures was determined at $4^{\circ} \mathrm{C}, 30^{\circ} \mathrm{C}$ and $35^{\circ} \mathrm{C}$. Once a day, over a period of three days and in the sixth day, two vials were stared at each storage temperature. All vials and two vials stored at $\leq-70^{\circ} \mathrm{C}$ ( 0 day) were examined at the end of the study period (isochronous stability study) [19]. The counts obtained for each storage temperature were $\log _{10}$ transformed and analyzed using linear regression [5].

\section{Results and Discussion}

\subsection{Preparation of the Reference Material}

A bath of 216 units of RM containing E. coli was manufactured and tested for their quality. Although it is known that PT samples should resemble as closely as possible to routine samples analyzed by participant laboratories, it is a common practice to produce lyophilized samples in order to improve analyte stability [9$11,20]$. All vials presented vacuum and satisfactory appearance after freeze-drying. The freeze-drying process was considered satisfactory, since the integrity of the product was not compromised over time as demonstrated by the stability profile shown by the reference material.

The ultra-filtered cheese sample presented a number of total viable aerobic micro-organisms of $1.2 \times 10^{3} \mathrm{CFU} / \mathrm{g}$. The presence of natural competing micro-organisms in the RM is important to demonstrate the real ability of the laboratory to enumerate the target(s) micro-organism(s) in a food sample [6].

\subsection{Homogeneity of the Reference Material}

The results of the analyses of the homogeneity study are presented in Table 1. The Cochran test did not identified outliers counts. The results of the homogeneity studies were obtained using one-factorial analysis of variances (1-way ANOVA). As the criteria $s_{\text {sam }}^{2}<c$ is met, the bath was considered sufficiently homogenous, with a confidence level of $95 \%$.

The freeze-drying process has already been successfully used in the production of homogeneous RM in skim milk matrix $[9,10]$. A homogeneous RM produced in this same ultra-filtered cheese matrix containing coagulasepositive staphylococcus (CPS) was also been described [11]. The publication of others studies about production of RM in other types of food matrix is rare due to the difficulties in obtaining homogeneous and stable materials and because the some producers do not have interest in disclosing their production techniques. In this study, the procedure developed has succeeded in producing a sufficiently homogeneous RM containing $E$. coli in ultra-filtered cheese matrix.

\subsection{Stability of the Reference Material}

The results of the long-term stability analyses from May 2012 to March 2013 at $\leq-70^{\circ} \mathrm{C}$ and from June 2012 to November 2012 at $-20^{\circ} \mathrm{C}$ are present in Figure 1.

Figure 2 presents the results of the stability test at higher temperatures, simulating transport conditions, over a period of 6 days.

The material was considered stable at $\leq-70^{\circ} \mathrm{C},-20^{\circ} \mathrm{C}$

Table 1. Summary of the statistical results from homogeneity studies of test materials containing coliforms.

\begin{tabular}{cccccccc}
\hline Analyte & Average $\left(\log _{10} \mathrm{CFU} / \mathrm{g}\right)$ & $\sigma_{\mathrm{p}}\left(\log _{10} \mathrm{CFU} / \mathrm{g}\right)$ & $\sigma_{\text {all }}^{2}$ & $s_{\text {sam }}^{2}$ & $s_{\text {sam }}^{2}$ & $c$ & Result \\
\hline Coliforms & 2.65 & 0.35 & 0.011 & 0,0040 & 0.017 & 0.019 & Sufficiently homogenous \\
\hline
\end{tabular}




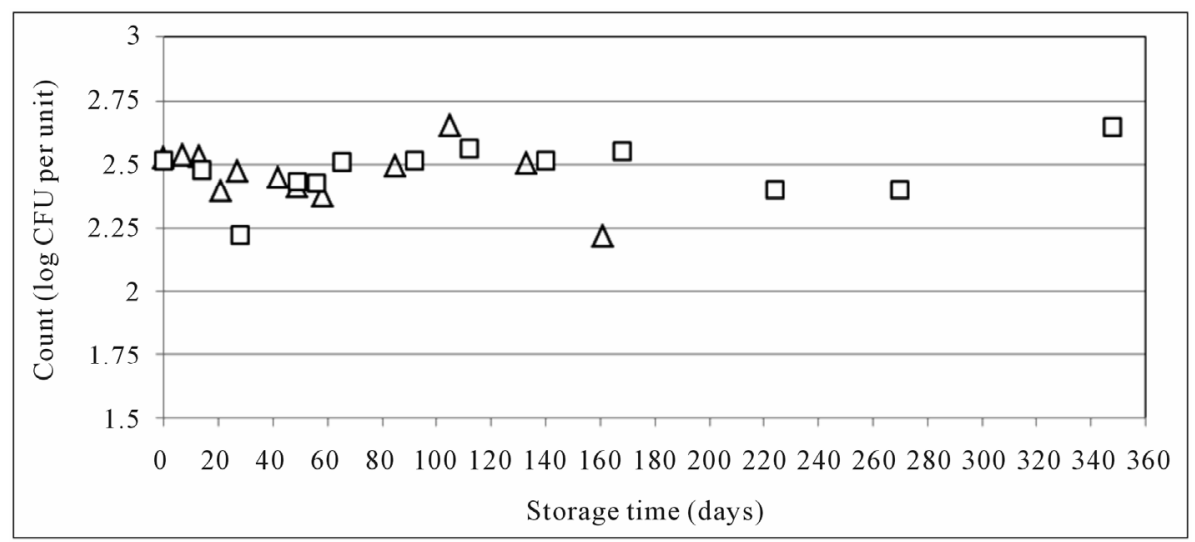

Figure 1. Results of stability tests at reference and storage temperatures: $(\triangle), \leq-70^{\circ} \mathrm{C} ;(\square),-20^{\circ} \mathrm{C}$. Each point corresponds to the mean count of two RM units (in $\log _{10} \mathrm{CFU} / \mathrm{g}$ per unit).

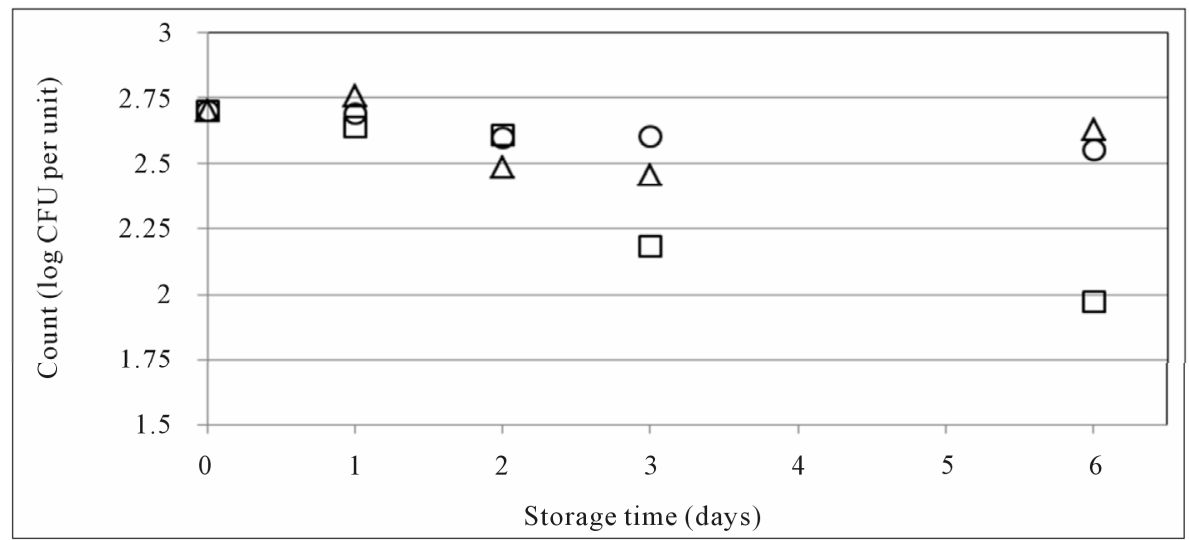

Figure 2. Results of stability tests at various temperatures: $(\triangle), 4^{\circ} \mathrm{C} ;(O), 25^{\circ} \mathrm{C} ;(\square), 35^{\circ} \mathrm{C}$ over a period of 6 days. Each point corresponds to the mean count of two RM units (in $\log _{10} \mathrm{CFU} / \mathrm{g}$ per unit).

and $4^{\circ} \mathrm{C}$ according to ISO guide 35 [5], since no significant change in number of $\mathrm{CFU}$ over the period tested when using linear regression. As zero value is within the confidential interval, the slope is not statistically significant, and there were no detectable changes in coliforms concentration in the course of the study times. However, the $\mathrm{RM}$ was not stable at the high temperatures of $30^{\circ} \mathrm{C}$ and $35^{\circ} \mathrm{C}$ (Table 2).

Bacterial counts of the long-term stability test at reference and storage temperature were stable for almost 1 year and half a year, respectively. The variability in number of CFU observed is regarded as of no, or minor, importance because the values of the slope for both temperatures are very small (Table 2). Literature data show that RM produced in lyophilized skim milk matrix are stable for periods up to $\approx 237$ days stored at $\leq-70^{\circ} \mathrm{C}$ $[9,10]$. In cheese matrix, Brandao et al. [11] obtained a RM containing CPS stable for 10 mouths at $\leq-70^{\circ} \mathrm{C}$. Similar results were obtained in this study, where the RM batch produced was stable for 348 days ( $\approx 12$ mouths). The $\mathrm{RM}$ also remained stable at $-20^{\circ} \mathrm{C}$ throughout the study period, with a value of slope similar to the reference temperature (Table 2). This result indicates that the RM likely to remain stable in this condition for a longer period of time. Rosas et al. [9] observed that the storage for long periods at $-20^{\circ} \mathrm{C}$ can compromise the stability of freeze-dried skim milk RM. These authors have produced two batches containing Salmonella spp. stable for three months, but with a tendency to decrease in cell concentration, and one year after the RM did have insufficiently stability. This result indicates that the material containing E. coli produced in this study has a more lasting stability than those produced by Rosas et al. [9]. This observation may be related to the fact that the use of sucrose as a cryo-protector may have provided greater stability of micro-organisms in the matrix, since in the study realized by Rosas et al. (2010) no cryo-protector additive was added to the matrix. This observation was also reported by Brandao et al. [11], that used this cryo-protector to produce a RM containing CPS stable at $-20^{\circ} \mathrm{C}$ for 48 days with a value of the slope of 0.00075 $\mathrm{CFU} / \mathrm{g}$ per day. Sucrose was selected as cryo-protector in this study because is the most frequently carbohydrate used to preserve micro-organisms by freeze-drying [13]. 
Table 2. Linear regression of the stability studies.

\begin{tabular}{|c|c|c|c|c|c|}
\hline \multirow{2}{*}{ Storage temperature } & \multirow{2}{*}{ Time of storage (days) } & \multirow{2}{*}{ Slope per day $(\mathrm{CFU} / \mathrm{g})$} & \multicolumn{2}{|c|}{$95 \%$ Confidence interval } & \multirow{2}{*}{ Result } \\
\hline & & & Lower & Higher & \\
\hline$-70^{\circ} \mathrm{C}$ & 348 & 0.00034 & -0.00027 & 0.00095 & Sufficiently stable \\
\hline$-20^{\circ} \mathrm{C}$ & 161 & -0.00067 & -0.0021 & 0.00072 & Sufficiently stable \\
\hline $4^{\circ} \mathrm{C}$ & 4 & -0.019 & -0.12 & 0.080 & Sufficiently stable \\
\hline $30^{\circ} \mathrm{C}$ & 4 & -0.025 & -0.046 & -0.0044 & Insufficiently stable \\
\hline $35^{\circ} \mathrm{C}$ & 4 & -0.13 & -0.22 & -0.046 & Insufficiently stable \\
\hline
\end{tabular}

The production of stable RM for longer extended to higher temperatures is important because not all laboratories have equipment to store the samples at $\leq-70^{\circ} \mathrm{C}$. Thus, the laboratories that acquire these RM could store them in more usual equipment such as common freezers and use them on a higher shelf life.

A short-term stability was performed in order to assess the possible effect of transport at different temperatures on the stability of the material. The stability data at $4{ }^{\circ} \mathrm{C}$ indicate that normal (air) mail with cooling of the RM is possible for shipment to other laboratories if the transport time is limited to six days. At high temperatures $\left(30^{\circ} \mathrm{C}\right.$ and $35^{\circ} \mathrm{C}$ ) the $\mathrm{RM}$ was not stable in the period of six days. These results were different from those obtained by Brandao et al. [11] who observed stability at $35^{\circ} \mathrm{C}$ for up to 4 days. This observation may be related to the fact that Gram-negative bacteria, as in the case the strain E. coli, usually showed a greater rate of decline than Grampositive bacteria [8,21], like the strain of Staphylococcus aureus subsp. aureus used by Brandao et al. [11]. The instability of the RM at temperatures $\geq 30^{\circ} \mathrm{C}$ limits the transportation of PT items at room temperature. Further studies are needed to increase the resistance of microorganisms to higher temperatures, since the transport under refrigeration enhances the final cost of PT.

According to the databases consulted in the literature, the present study was the first to describe a methodology for the production of RM containing $E$. coli in cheese matrix. The development of methodologies for the production of RM in different matrices and containing the various classes of micro-organisms of interest in public health is important to increase the scope of the PT programs and consequently improving the quality of the analytical laboratories of food microbiology.

\section{Conclusion}

This paper describes the development of the first quantitative RM containing E. coli in cheese matrix produced by freeze-drying. The spiked material showed adequate homogeneity and stability and it is applicable for a PT. As proved stable under the used stored conditions, re- maining PT items can be provided as internal quality control materials. As long as this batch of RM is available for use, the monitoring of its stability will continue.

\section{Acknowledgements}

Conselho Nacional de Desenvolvimento Científico e Tecnológico (CNPq), Inovatec/Fiocruz and INCQS/Fiocruz for financial support.

\section{REFERENCES}

[1] M. Koch, W. Bremser, R. Köppen, R. Krüger, T. Rasenko, D. Siegel and I. Nehls, "Certification of Reference Materials for Ochratoxin A Analysis in Coffee and Wine," Accreditation Quality Assurance, Vol. 16, No. 8-9, 2011, pp. 429-437. doi: 10.1007/s00769-011-0783-0

[2] W. J. Philipp, P. van Iwaarden, H. Schimmel, N. Meeus and N. Kollmorgen, "Development of Reference Materials for Microbiological Analysis," Accreditation Quality Assurance, Vol. 12, No. 3-4, 2007, pp. 134-138. doi: 10.1007/s00769-006-0244-3

[3] M. Abdelmassih, V. Planchon, C. Anceau and J. Mahillon, "Development and Validation of Stable Reference Materials for Food Microbiology Using Bacillus cereus and Clostridium perfringens Spores," Journal of Applied Microbiology, Vol. 110, No. 6, 2011, pp. 1524-1530. doi:10.1111/j.1365-2672.2011.05007.x

[4] ISO/IEC 17025, "General Requirements for the Competence of Testing and Calibration Laboratories," ISO, Geneva, 2005.

[5] ISO Guide 35, "Reference Materials - General and Statistical Principles for Certification," ISO, Geneva, 2006.

[6] P. H. in't Veld, S. H. W. Notermans and M. van de Berg, "Potential Use of Microbiological Reference Materials for the Evaluation of Detection Methods for Listeria monocytogenes and the Effect of Competitors: A Collaborative Study," Food Microbiology, Vol. 12, No. 2, 1995, pp. 125-134.

[7] P. H. in't Veld, A. H. Havelaar and N. G. W. M. van Strijp-Lockefeer, "The Certification of a Reference Material for the Evaluation of Methods for the Enumeration of Bacillus cereus," Journal of Applied Microbiology, Vol. 86, No. 2, 1999, pp. 266-274. doi:10.1046/i.1365-2672.1999.00661.x 
[8] M. Peterz and A. C. Steneryd, "Freeze-Dried Mixed Cultures as Reference Samples in Quantitative and Qualitative Microbiological Examinations of Food," Journal of Applied Bacteriology, Vol. 74, No. 2, 1993, pp. 143-148. doi:10.1111/j.1365-2672.1993.tb03007.x

[9] C. O. Rosas, M. L. L. Brandao, S. M. L. Bricio, V. M. Medeiros, S. P. C. Bernardo, M. H. C. De La Cruz and P. Cardarelli-Leite, "Desenvolvimento de Material de Referência para Ensaio de Proficiência em Microbiologia de Alimentos," Revista do Instituto Adolfo Lutz, Vol. 69, No. 1, 2010, pp. 15-22.

[10] M. L. L. Brandao, C. O. Rosas, S. M. L. Bricio, J. C. B. Costa, V. M. Medeiros and M. B. Warnken, "Produção de Materiais de Referência para Avaliação de Métodos Microbiológicos em Alimentos: Estafilococos Coagulase Positiva e Listeria spp. em leite em pó," Revista Analytica, Vol. 63, 2013, pp. 60-71.

[11] M. L. L. Brandao, J. C. B. Costa, F. M. Farias, C. O. Rosas, S. M. L. Bricio, J. S. Nascimento and P. Cardarelli-Leite, "Development of Reference Material for the Microbiology of Foods Containing Coagulase-Positive Staphylococcus in a Cheese Matrix," Brazilian Journal of Food Technology, Vol. 16, No. 1, 2013, pp. 73-79. doi:10.1590/S1981-67232013005000006

[12] C. A. Morgan, N. Herman, P. A. White and G. Vesey, "Preservation of Micro-Organisms by Drying: A Review," Journal of Microbiology Methods, Vol. 66, No. 2, 2006, pp. 183-193. doi:10.1016/j.mimet.2006.02.017

[13] Z. Hubálek, "Protectants Used in the Cryopreservation of Microorganisms," Cryobiology Methods, Vol. 46, No. 3, 2003, pp. 205-229. doi:10.1016/S0011-2240(03)00046-4

[14] Brasil, "Ministério da Saúde, Agência Nacional de Vigilância Sanitária,” RDC No. 12, 26 January 2001.

[15] ISO Guide 34, "General Requirements for the Compe- tence of Reference Materials Producers," ISO, Geneva, 2009.

[16] P. Feng, S. D. Weagant, M. A. Grant and W. Burkhardt, "2002, Chapter 4. Enumeration of Escherichia coli and the Coliform Bacteria," In: Food and Drug Administration (FDA), Bacteriological Analytical Manual Online, 8th Edition, Silver Spring, Berlin, 1998.

[17] L. Maturin and J. T. Peeler, "2001, Chapter 3. Aerobic Plate Count," In: Food and Drug Administration (FDA), Bacteriological Analytical Manual Online, 8th Edition, Silver Spring, Berlin, 1998.

[18] M. Thompson, S. L. R. Ellison and R. Wood, "International Harmonized Protocol for Proficiency Testing of (Chemical) Analytical Chemistry Laboratories," Pure and Applied Chemistry, Vol. 78, No. 1, 2006, pp. 145-196. doi:10.1351/pac200678010145

[19] A. Lamberty, H. Schimmel and J. Pauwels, "The Study of the Stability of Reference Materials by Isochronous Measurements," Fresenius Journal Analytical Chemistry, Vol. 360, No. 3-4, 1998, pp. 359-361. doi: $10.1007 / \mathrm{s} 002160050711$

[20] B. F. Spisso, M. A. Monteiro, M. U. Pereira, R. G. Ferreira, R. P. da Costa, B. S. Carlos, S. T. C. Negris, M. H. C. De La Cruz and A. W. da Nóbrega, "Preparation of In-House Reference Material of Benzylpenicillin in Milk and Results of a Brazilian Proficiency Testing Scheme," Accreditation Quality Assurance, 2013. (in Press) doi:10.1007/s00769-013-0982-y

[21] P. Wessman, D. Mahlin, S. Akhtar, S. Rubino, K. Leifer, V. Kessler and S. Hákansson, "Impact of Matrix Properties on the Survival of Freeze-Dried Bacteria," Journal of Scientific and Food Agriculture, Vol. 91, No. 14, 2011, pp. 2518-2528. doi:10.1002/jsfa.4343 